\title{
Patterns of Export Diversification: Evidence from Pakistan
}

\section{Hamna Ahmed* and Naved Hamid**}

\begin{abstract}
This paper examines historical trends in the diversification of exports in Pakistan, using the Hirschman index to quantify the degree of export diversification. We analyze the structure of exports through the lens of 'traditionality,' for which we construct industry-specific, average cumulative export experience functions, i.e., a traditionality index of all 2-digit export industries in Pakistan from 1972 to 2012. This is useful in distinguishing between traditional and nontraditional export industries. We also study the degree of structural change in the export sector since 1972 by recalculating the traditionality index based on five-year interval periods. The cross-industry variance of this index is then used to calculate the structural change index. Periods for which the index values are low are interpreted as periods during which the export industries experienced uniform patterns of export growth (and thereby no structural change). Periods for which the index values are high are interpreted as periods during which the export industries experienced varied patterns of growth, thus undergoing structural change. Finally, we explore the determinants of structural change in exports by looking at variables such as GDP growth, export growth, the real exchange rate, the growth rate of world trade, trade liberalization, and the degree of product concentration in the country's export base.
\end{abstract}

Keywords: Pakistan, export, growth, trade.

\section{JEL classification: F40.}

\section{Introduction and Literature Review}

The trade literature has identified the diversification of exports as an important ingredient of long-term sustainable growth (see RosensteinRodan, 1943; Presbisch, 1950; Singer, 1950; Vernon, 1966; Krugman, 1979; Grossman \& Helpman, 1991; Gutiérrez-de-Piñeres \& Ferrantino, 1997). Trade theory, too, has been supplemented by the experience of developing countries. The "East Asian miracle," for instance, showed how countries'

\footnotetext{
* Research Fellow, Centre for Research in Economics and Business, Lahore School of Economics, and $\mathrm{PhD}$ candidate at the University of Kent, UK.

*** Director, Centre for Research in Economics and Business, Lahore School of Economics.
} 
ability to introduce new products within existing industries (horizontal diversification) and to move production from low value-added sectors to high value-added sectors (vertical diversification) could serve as a powerful driver of growth.

Several empirical studies have also established the importance of product diversification for exports and GDP growth. For a sample of 91 countries, Al-Marhubi (2000) shows that diversification promotes growth. Hausman, Hwang, and Rodrik (2005) explain the export performance of various countries in terms of the mix of commodities they produce. By constructing PRODY and EXPY indices, they show that productivity levels differ across commodities: some yield high levels of productivity while others are associated with low productivity levels. Countries able to position their export baskets around the high-productivity end of the spectrum exhibit higher rates of growth.

There are several reasons to believe that export diversification is necessary for an effective trade policy. For instance, studies show that diversification helps mitigate the negative effects of economic shocks. In the short run, dependence on a few commodities would imply that foreign exchange earnings are highly volatile in response to changing demand and supply conditions. Diversification is considered especially important for developing countries, which tend to specialize in the production of primary commodities as a means to counter the adverse effects of declining terms of trade in the long run. Moreover, primary commodities have (i) a low-income elasticity and (ii) limited scope for developing forward and backward linkages. Thus, from a long-term perspective, the prospects of raising future revenues from the export of primary commodities and the possibility of benefiting from growth spillovers are limited.

Regarding Pakistan, Ahmed, Hamid, and Mahmud (2013) argue that

the country's share of world exports has remained more or less stagnant over the past three decades. This reflects the country's inability to expand exports faster than world trade (see Table 1). On the other hand, its South Asian neighbors and the East Asian countries have shown a tremendous increase in export shares. Malaysia and Thailand entered their rapid export growth phase in the 1980s and 1990s, while Bangladesh and India started theirs in the 1990s, which continues to date. India has managed to increase its export share almost fourfold and 
Bangladesh by more than three times since 1980. As a result, Pakistan's exports, which were more than a third of India's and almost four times that of Bangladesh in 1980, are now less than one tenth of India's and about the same as Bangladesh. The latter has achieved this tremendous export growth on the back of its garments sector, and today Bangladesh exports garments worth over USD 14 billion, which is almost four times the value of Pakistan's garment exports.

Table 1: Country-wise share of world exports (1980-2011)

\begin{tabular}{lccccc}
\hline Country & $\mathbf{1 9 8 0}$ & $\mathbf{1 9 9 0}$ & $\mathbf{2 0 0 0}$ & $\mathbf{2 0 1 0}$ & $\mathbf{2 0 1 1}$ \\
\hline Bangladesh & 0.04 & 0.05 & 0.09 & $0.14^{*}$ & $\mathrm{~N} / \mathrm{A}$ \\
India & 0.43 & 0.57 & 0.70 & 1.55 & 1.78 \\
Pakistan & 0.15 & 0.18 & 0.15 & 0.15 & 0.15 \\
Malaysia & 0.74 & 0.94 & 1.61 & 1.40 & 1.34 \\
Thailand & 0.37 & 0.74 & 1.13 & 1.37 & 1.35 \\
\hline
\end{tabular}

Note: * Bangladesh's data is for 2007.

Source: Authors' calculations based on data from the UN Commodity Trade database.

The historical lack of product diversification is considered an important reason for Pakistan's poor export performance. Using the Gini Hirschman index, ${ }^{1}$ we analyze the degree of product diversification in Pakistan's exports from 1972 to 2012 (Figure 1). What we find echoes our findings in an earlier study (see Ahmed, Mahmud, Hamid, \& Rahim, 2010) undertaken for the Planning Commission of Pakistan. While concentration levels were high during the 1990s, there has been an increasing trend toward diversification since 2003. In 2012, Pakistan's product concentration index stood at 0.42 . In 2008, 15 commodities accounted for more than 90 percent of the country's exports; by 2012, this number had increased to 17.

Thus, while there has been some improvement in broadening Pakistan's export base, the index remains substantially higher than that of comparator countries such as Malaysia, Thailand, and India. A recent study by the World Bank (2013) discusses various structural and emerging constraints that are slowing down Pakistan's ability to continue the process of product diversification.

${ }^{1}$ Following Akbar and Naqvi (2001), this index is calculated using the formula where represents the export share of commodity $i$ in total exports for year $t$, while $k$ represents the total commodities that account for more than 90 percent of the country's export basket. The index ranges between 0 and 1 , where 1 reflects perfect concentration and 0 perfect diversification. 
In this study, we extend Ahmed et al. (2010) by exploring in detail product diversification patterns in Pakistan. We argue that, while Ahmed et al. (2010) provide a good understanding of how aggregate diversification has changed in the export base, their approach does not allow for a microlevel investigation of the process of diversification. Using the Hirschman index to assess concentration is equivalent to measuring it purely on the basis of the number of commodities in the export base-this is a rather narrow approach to measuring product diversification.

Figure 1: Product concentration index (1972-2012)

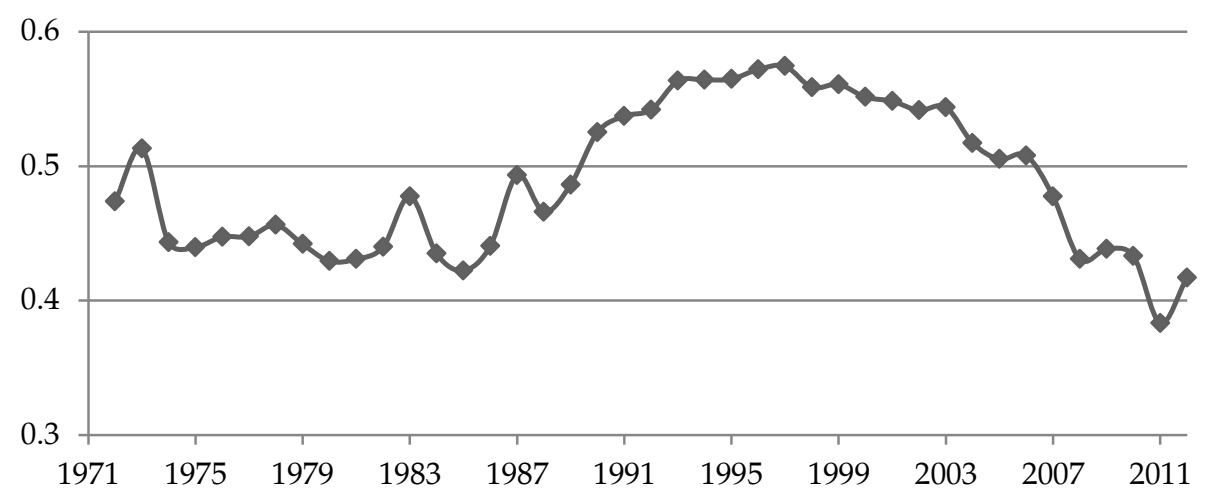

Source: Authors' calculations based on data from the UN Commodity Trade database.

The literature lends merit to this claim. Hausmann et al. (2005) show that a country's growth is affected by what it exports. In an attempt to understand the constraints to Pakistan's export performance, the World Bank (2013) employs five different measures of diversification: (i) the expansion of the product and market base, (ii) the growth of the extensive versus the intensive margin, (iii) the share of high-tech products in the export basket, (iv) the degree of export sophistication, and (v) the degree of export connectedness.

The first measure calculates the degree of diversification using the Herfindahl index on the basis of concentration (or otherwise) in certain products or markets. The second measure analyzes the growth of exports in 'new' products and industries (extensive margin) versus the growth of 'old' products and industries (intensive margin). The third compares the share of high-tech and low-tech exports in the country's export basket. Sophistication levels are assessed using the indices employed by Hausmann et al. (2005), which are based on a weighted average of each commodity's share of total exports; the weights represent the average per capita income of countries that produce similar products. Finally, using 
their ideas, export connectedness is defined on the basis of the location of industries in the 'forest,' i.e., whether they are located in dense or thin parts of the forest.

Concentration levels in products and markets have gone down over time. Growth at the extensive margin has been sluggish relative to the intensive margin. While the country is moving into new products and markets, this process has been very slow. The share of high-tech products in the export basket has remained stagnant, not having moved beyond 2 percent since the 1980s. The share of low-tech exports has, however, continued to increase-from 54 percent in the 1980s to 65 percent in 2008. Pakistan's exports lag behind in sophistication compared to other Asian countries such as India, Thailand, China, and the Philippines. Finally, most export industries are still located in the thin parts of the forest with limited opportunities for moving up the value chain. Overall, Pakistan appears to be faring poorly on all indicators of export diversification except for the first. These findings motivate the need to move away from narrow measures of diversification in order to understand the export industry's underlying dynamics, in other words changes over time.

Motivated by this line of work, we augment the conventional measure of diversification, the Gini Hirschman index, with an analysis of the extent of traditionality and structural change in the export sector. Following Gutiérrez-de-Piñeres and Ferrantino (1997), we do so by constructing an average traditionality index (ATI) for each industry and a structural change index (SCI) for each year since 1972. The ATI is the mean of the cumulative export index for each industry while the SCI is the variance of the ATI calculated across industries but using five-year intervals rather than the full sample period.

Our study has three main objectives: (i) to assess the degree of traditionality in all 2-digit export industries over time; (ii) to study the degree of medium-term structural change that has occurred in the country's export sector from 1972 to 2012; and (iii) to explore the determinants of this structural change, which could help identify factors that would boost the country's export performance in the future.

A distinguishing feature of this research is our approach to analyzing structural change. In an earlier study by Felipe (2007), structural change has been analyzed using an external lens, i.e., by comparing the degree of structural change in Pakistan with respect to other comparator countries in Asia. However, in this paper, we adopt an internal lens for 
analyzing structural change by looking at patterns of change across industries and within industries since 1972.

\section{Data and Methodology}

The study employs industry-level trade data at the 2-digit level taken from the United Nations Statistics Division (2014). The data cover a period of 40 years from 1972 to 2012. In order to assess the degree of traditionality for each industry $(k)$, we calculate a cumulative export experience function or traditionality index (trad) for year $t$ using the following formula:

$$
\operatorname{trad}_{t}^{k}=\sum_{1972}^{t} e_{t}^{k} / \sum_{1972}^{2012} e_{t}^{k}
$$

The numerator contains the cumulative sum of real exports (e) starting from the initial time period $t_{0}$ (in this case, is 1972) up until period $t$; the denominator contains the total sum of real exports for industry $k$ from 1972 to 2012. The means of these export experience functions are used to obtain the average level of traditionality for each industry as follows:

$$
\text { avg_trad }^{k}=\sum_{t_{o}}^{T} \operatorname{trad}_{t}^{k} / T-t_{0}+1
$$

Each industry's cumulative export experience function ranges between 0 and 1 . An industry for which the export experience function is close to 1 is classified as traditional and vice versa. In other words, the formulae for these indices predict that a traditional industry is one for which the export experience was concentrated earlier in the sample period while a nontraditional industry is one for which the export experience was concentrated later in the sample period.

Once the ATI (avg_trad) for each industry has been calculated for the period under study (1972-2012), we rank all industries on the basis of this mean index. The industry with the lowest ATI (avg_trad) will be ranked 1 while the industry with the highest ATI (avg_trad) will be ranked 30. Although there are 65 export industries at the 2-digit level, we focus our attention on the top 30, which, collectively, accounted for 96.93 percent of Pakistan's total exports in 2012. In addition to avg_trad, we will calculate its variance for each industry over time. These are referred to as withinindustry (or intra-industry) variances, reflecting the deviation of each industry's $(k)$ avg_trad from its average value over the period of study. 
Next, we investigate the degree of medium-term structural change in the country's export sector since 1972. For this purpose, we will first recalculate the cumulative export experience functions for each of the top 30 2-digit industries using five-year intervals instead of the full sample period as used before. This is done using the following formula:

$$
\operatorname{trad} 5_{t}^{k}=\frac{\sum_{t-2}^{t} e_{t}^{k}}{\sum_{t-2}^{t+2} e_{t}^{k}}
$$

The $\operatorname{trad} 5_{t}^{k}$ index will be used to calculate the inter-industry variance for each year $t$ as shown by equation (3b).

$$
s c_{t}=\operatorname{Var}\left(\operatorname{trad} 5_{k 0}^{k}\right)_{t}
$$

We expect these inter-industry variances over time to prove useful in understanding the degree of medium-term structural change in the country's export sector over time. Periods in which the inter-industry variance is low will reflect stable trends in the export sector while periods in which the inter-industry variance is high can be interpreted as periods of structural change with differing patterns across industries-some leading while others lag behind in terms of export performance.

The final part of the analysis entails studying the determinants of structural change, using the following regression model:

$$
\begin{aligned}
& S C_{t}=\alpha+\beta_{1} \text { Liberalization }_{t}^{P K}+\beta_{2} P C I_{t}^{P K}+\beta_{3} \log (R E R)_{t}^{P K}+ \\
& \beta_{4} G D P \text { growth } \\
& \text { PK }
\end{aligned}
$$

where the $s c_{t}$ index represents the degree of structural change as measured by the inter-industry variance of the trad5 index each year, GDPgrowth ${ }_{t}^{P K}$ measures growth rate of real GDP for Pakistan, Exgrowth ${ }_{t}^{P K}$ measures Pakistan's growth rate of exports, Tradegrowth $t^{\text {WORLD }}$ represents growth rate of world trade and $\varepsilon_{t}$ represents the error term. 
Liberalization $_{t}^{P K}$ measures the degree of trade liberalization for each year as given by the ratio of import duty revenue to total non-oil, non-food imports of the country (shown by (5) above). An increase (a decrease) in the ratio of import duty revenue to non-oil, non-food imports would imply a decrease (increase) in trade liberalization.

$\mathrm{PCI}_{t}$ is the product concentration index of the country's export sector for each period $t . W_{i t}$ represents the export share of commodity $i$ in total exports for year $t$, while $k$ represents the total commodities that account for more than 90 percent of the country's export basket. The index ranges between 0 and 1: an increase (decrease) in this index would imply an increase (decrease) in concentration levels, or, in other words, a decrease (increase) in diversification.

$R E R_{t}^{P K}$ measures the country's real exchange rate as given by the ratio of the prices of tradable and non-tradable goods. The product of the nominal exchange rate (of the local currency with regards to the US dollar) and the US whole price index is used as a proxy for the price of tradable goods while Pakistan's consumer price index is used as a proxy for the price of non-tradable goods for each year $(t)$. An increase in this ratio would imply depreciation of the rupee with regards to the dollar, and therefore an increase in competitiveness of the export sector and vice versa.

The data used for the regression analysis has been compiled from various sources. These include the United Nations Statistics Division (UN Comtrade), the UNCTAD Handbook of Statistics 2008, various rounds of the Pakistan Economic Survey, the State Bank of Pakistan's annual reports, and the World Development Indicators database.

\section{Results}

This section presents our calculations of traditionality levels across the export sector and the disaggregated pool of export industries as well as the SCI over time.

\subsection{Traditionality Levels Across Export Industries}

Tables 2 and 3 below present results for Pakistan's top 30 export industries. Cumulatively, these industries accounted for 97 percent of the country's total exports in 2012. (Table A1 in the Annex (column 5) ranks the top 30 2-digit export industries by traditionality.) For each of these industries, we have calculated a year-wise cumulative export experience function for 1972-2012, the means of which, or ATI, are given in column 3. 
Industries with a smaller ATI are classified as less traditional and vice versa. The traditionality rank ranges from 1 to 30 where 1 denotes the least traditional and 30 the most traditional industry.

Table 2: Traditionality ranks of the top five export industries

(SITC 2-digit level)

\begin{tabular}{|c|c|c|c|c|c|}
\hline (1) & (2) & (3) & (4) & (5) & (6) \\
\hline $\begin{array}{l}\text { UN } \\
\text { code }\end{array}$ & Description & ATI & $\begin{array}{c}\text { Variance of } \\
\text { traditionality } \\
\text { index }\end{array}$ & $\begin{array}{c}\text { Traditionality } \\
\text { rank }\end{array}$ & $\begin{array}{l}\text { Share of total } \\
\text { exports (2012) }\end{array}$ \\
\hline 65 & $\begin{array}{l}\text { Textile yarn, fabrics, } \\
\text { made-up articles, } \\
\text { related products }\end{array}$ & 0.363 & 0.092 & 19 & 35.37 \\
\hline 84 & $\begin{array}{l}\text { Articles of apparel, } \\
\text { clothing accessories }\end{array}$ & 0.288 & 0.098 & 12 & 17.12 \\
\hline 04 & $\begin{array}{l}\text { Cereals and cereal } \\
\text { preparations }\end{array}$ & 0.438 & 0.066 & 23 & 9.44 \\
\hline 89 & $\begin{array}{l}\text { Misc manufactured } \\
\text { articles }\end{array}$ & 0.306 & 0.075 & 15 & 8.62 \\
\hline 66 & $\begin{array}{l}\text { Nonmetallic mineral } \\
\text { manufactures }\end{array}$ & 0.218 & 0.051 & 8 & 2.55 \\
\hline
\end{tabular}

Source: Authors' calculations based on data from the UN Commodity Trade database.

Table 3: Traditionality ranks of the top five export industries in the UN89 category

(SITC 3-digit level)

\begin{tabular}{|c|c|c|c|c|c|}
\hline (1) & (2) & (3) & (4) & (5) & (6) \\
\hline $\begin{array}{l}\text { UN } \\
\text { code }\end{array}$ & Description & ATI & $\begin{array}{c}\text { Variance of } \\
\text { traditionality } \\
\text { index }\end{array}$ & $\begin{array}{c}\text { Traditionality } \\
\text { rank }\end{array}$ & $\begin{array}{l}\text { Share of total } \\
\text { exports (2012) }\end{array}$ \\
\hline 897 & $\begin{array}{l}\text { Jewelry and } \\
\text { semiprecious } \\
\text { materials }\end{array}$ & 0.084 & 0.04 & 1 & 6.62 \\
\hline 894 & $\begin{array}{l}\text { Baby carriages, toys, } \\
\text { games, sporting goods }\end{array}$ & 0.393 & 0.11 & 7 & 0.89 \\
\hline 893 & $\begin{array}{l}\text { Articles, n.e.s. of } \\
\text { plastic }\end{array}$ & 0.194 & 0.07 & 3 & 0.44 \\
\hline 899 & $\begin{array}{l}\text { Misc manufactured } \\
\text { articles n.e.s. }\end{array}$ & 0.498 & 0.09 & 8 & 0.15 \\
\hline 892 & Printed matter & 0.522 & 0.09 & 9 & 0.04 \\
\hline
\end{tabular}

Source: Authors' calculations based on data from the UN Commodity Trade database.

Three main insights can be drawn from the results given in Tables A1, 2, and 3: 
- The inter-industry variation in the ATI shows that the cumulative export experience function of industries has differed over time from 1972 to 2012, with the least traditional industry enjoying an ATI of 0.095 and the most traditional industry with an ATI of 0.678.

- The share of the least traditional industries accounted for only a tenth of total exports in 2012. This is evident from the fact that the cumulative share of the top ten least traditional industries (those with a rank ranging from 1 to 10 in column 5, Table A1) in total exports was 9.45 percent in 2012 .

- Pakistan's top export industries (in terms of export share) emerge as the most traditional on the basis of this classification. This comes across starkly in Table 2, which gives the top five exports on the basis of their export share (column 6). These exports accounted for 73.1 percent of the country's total exports in 2012. On a traditionality scale of 1 to 30, three of the top five export industries are assigned a traditionality rank of 15 or higher. Moreover, this pool contains some of the most traditional industries, namely textile fibers and leather, which are ranked 29 and 25, respectively.

\subsection{Traditionality Levels Across the Disaggregated Pool of Export Industries}

Next, we analyze traditionality levels for the country's top five exports as well as for the small and medium enterprise (SME) sector. Following Ahmed et al. (2013), SME industries include miscellaneous manufactured articles (primarily sporting goods), scientific equipment (primarily surgical instruments), general industrial machinery and parts, road vehicles and parts, telecommunications and sound-recording equipment, power-generating machinery and equipment (primarily motors and fans), and specialized machinery for particular industries (primarily machine tools). Most of the export production of these products takes place in small and medium units in industrial clusters around Karachi, Lahore, and the Sialkot-Gujrat-Gujranwala triangle in central Punjab. Finally, the pool of agricultural industries is defined to include rice, meat and meat preparations, and fruits and vegetables.

Figures 2 and 3 plot the traditionality index for the top five export industries (at the SITC 2-digit level) and for the top five exports in the UN89 category (at the SITC 3-digit level). Industries for which the index lies to the left are considered more traditional than those for which the index lies to the right. As anticipated from Table 2, Figure 2 shows that 
some of the most important export industries-cereals and cereal preparations (i.e., rice) and textile yarn, fabrics, and made-ups (where both groups collectively accounted for 45 percent of total exports in 2012-are also the most traditional, their export experience functions positioned to the left. On the other hand, nonmetallic mineral manufactures (i.e., cement) and jewelry and semi-precious stones emerge as the least traditional export industries (Figures 2 and 3).

Figure 2: Traditionality levels across the top five export industries

(SITC 2-digit level)

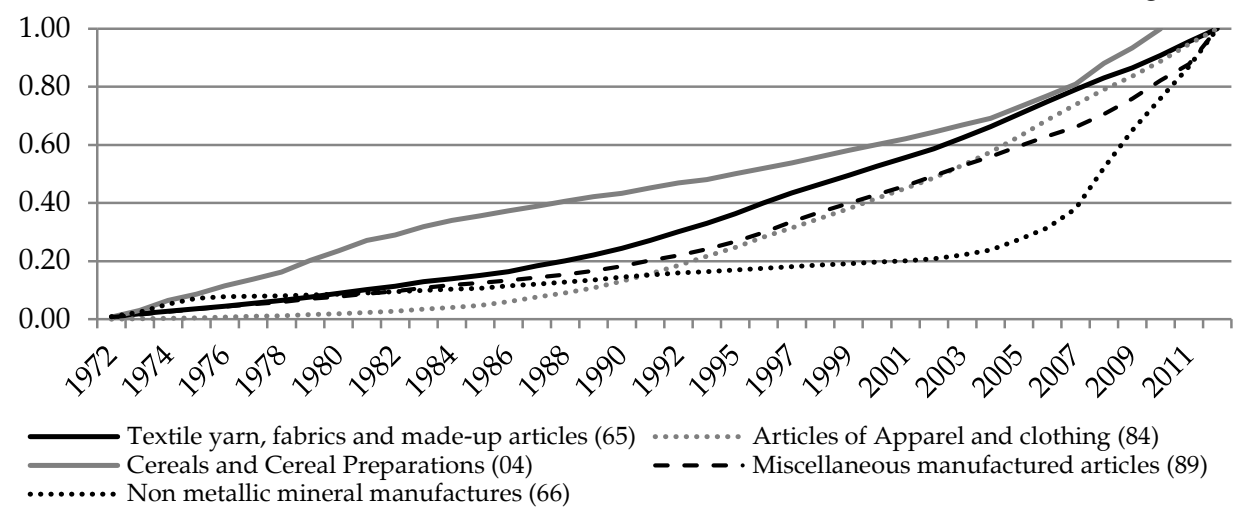

Source: Authors' calculations based on data from the UN Commodity Trade database.

\section{Figure 3: Traditionality levels across the top five export industries in} the UN89 category

(SITC 3-digit level)

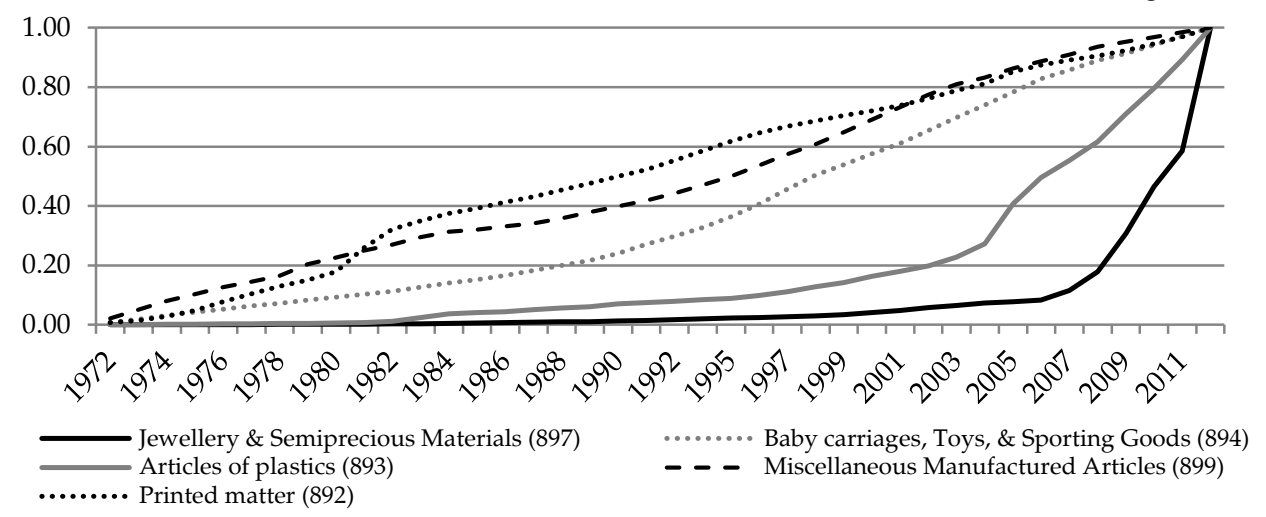

Source: Authors' calculations based on data from the UN Commodity Trade database.

Figure 4 compares the traditionality levels of each of the SME export industries according to the definition given earlier. Three particular 
industries emerge as the least traditional: furniture, power-generating machinery and equipment, and specialized machinery. The remaining SME export industries feature similar levels of traditionality.

Figure 4: Traditionality levels of SME industries, 1972-2012

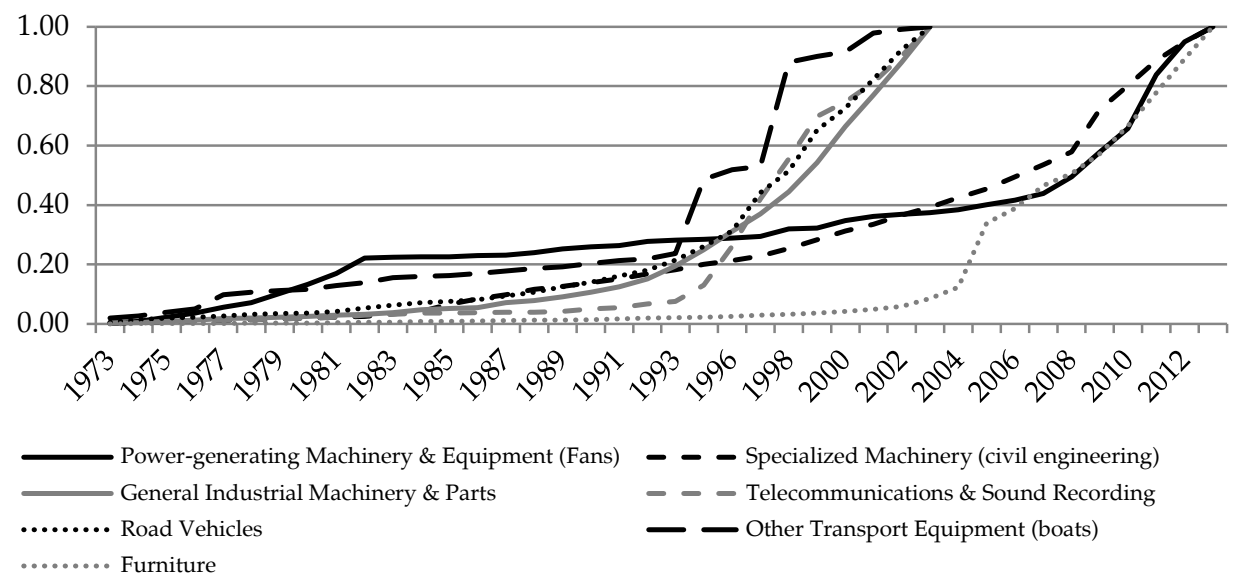

Source: Authors' calculations based on data from the UN Commodity Trade database.

\subsection{Structural Changes in the Export Sector Over Time}

Table 4 gives the SCI (calculated using the across-industry variations in traditionality levels for each year from 1976 to 2007, as explained in Section 2), along with data on some key macroeconomic variables such as the degree of trade liberalization, the growth rate of GDP, and the real exchange rate. The SCI is also plotted over time as shown in Figure 5, which is useful for looking at the overall direction of structural change in the export sector over time.

The data in Table 4 along with the product concentration index is used to estimate the regression model given by equation (4) in Section 2. The dependent variable is the SCI, which measures the inter-industry variance for each year. In order to rule out the possibility of a spurious correlation, the first difference of each series was regressed on its own oneperiod lag and a time variable. The results of these regressions show that the world growth rate of trade and Pakistan's export growth rate are stationary in levels, while the product concentration index is nonstationary in level but stationary in first difference. All the other variables-the SCI, trade liberalization, the real exchange rate, and Pakistan's GDP growth rate-are trend stationary. 
Figure 5: Annual SCI, 1972-2012

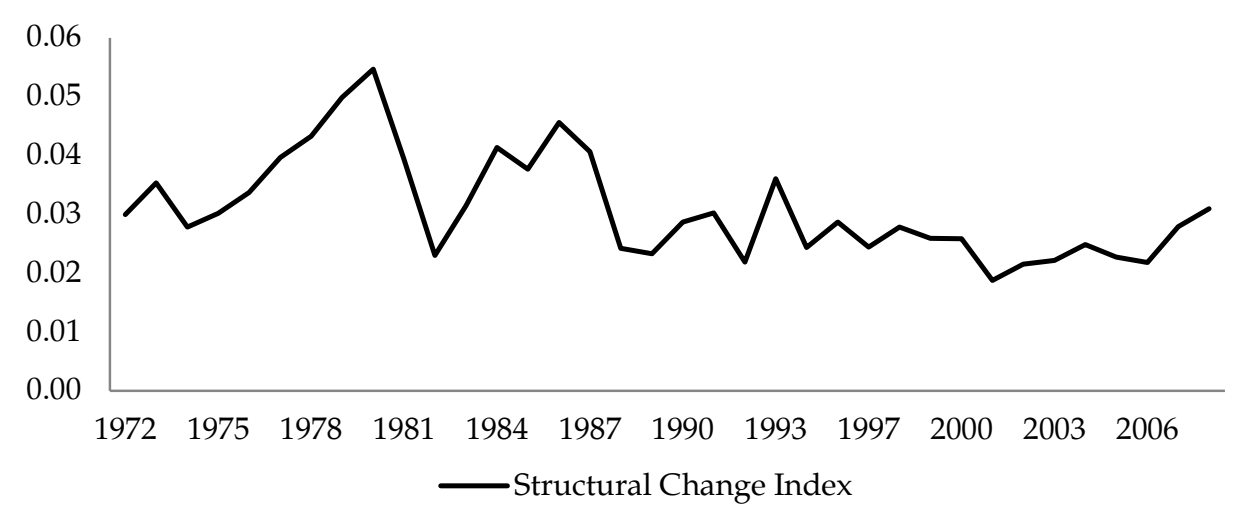

Source: Authors' calculations based on data from the UN Commodity Trade database. 
Table 4: SCI and other macroeconomic indicators

\begin{tabular}{|c|c|c|c|c|}
\hline Year & SCI & Trade liberalization & GDP growth rate & Real exchange rate \\
\hline 1972 & & & & 24.7 \\
\hline 1973 & & & 7.1 & 42.6 \\
\hline 1974 & 0.03 & & 3.5 & 37.5 \\
\hline 1975 & 0.04 & & 4.2 & 33.9 \\
\hline 1976 & 0.03 & & 5.2 & 33.1 \\
\hline 1977 & 0.03 & & 3.9 & 31.9 \\
\hline 1978 & 0.03 & & 8.0 & 32.4 \\
\hline 1979 & 0.04 & 0.452 & 3.8 & 33.7 \\
\hline 1980 & 0.04 & 0.419 & 10.2 & 34.3 \\
\hline 1981 & 0.05 & 0.454 & 7.9 & 33.5 \\
\hline 1982 & 0.05 & 0.395 & 6.5 & 39.7 \\
\hline 1983 & 0.04 & 0.463 & 6.8 & 40.8 \\
\hline 1984 & 0.02 & 0.339 & 5.1 & 41.8 \\
\hline 1985 & 0.03 & 0.431 & 7.6 & 45.1 \\
\hline 1986 & 0.04 & 0.498 & 5.5 & 44.5 \\
\hline 1987 & 0.04 & 0.520 & 6.5 & 45.0 \\
\hline 1988 & 0.05 & 0.485 & 7.6 & 44.6 \\
\hline 1989 & 0.04 & 0.418 & 5.0 & 50.9 \\
\hline 1990 & 0.02 & 0.519 & 4.5 & 49.9 \\
\hline 1991 & 0.02 & 0.433 & 5.1 & 49.9 \\
\hline 1992 & 0.03 & 0.249 & 7.7 & 47.4 \\
\hline 1993 & 0.03 & 0.248 & 1.8 & 47.2 \\
\hline 1995 & 0.02 & 0.355 & 8.9 & 44.8 \\
\hline 1996 & 0.04 & 0.311 & 4.8 & 47.0 \\
\hline 1997 & 0.02 & 0.265 & 1.0 & 48.7 \\
\hline 1998 & 0.03 & 0.243 & 2.6 & 50.8 \\
\hline 1999 & 0.02 & 0.201 & 3.7 & 54.9 \\
\hline 2000 & 0.03 & 0.195 & 4.3 & 56.4 \\
\hline 2001 & 0.03 & 0.157 & 2.0 & 67.9 \\
\hline 2002 & 0.03 & 0.119 & 3.2 & 60.1 \\
\hline 2003 & 0.02 & 0.147 & 4.8 & 59.4 \\
\hline 2004 & 0.02 & 0.131 & 7.4 & 59.0 \\
\hline 2005 & 0.02 & 0.123 & 7.7 & 59.6 \\
\hline 2006 & 0.02 & 0.098 & 6.2 & 58.4 \\
\hline 2007 & 0.02 & 0.102 & 4.8 & 57.1 \\
\hline 2008 & 0.02 & 0.082 & 1.7 & 58.8 \\
\hline 2009 & 0.03 & 0.084 & 2.8 & 56.2 \\
\hline 2010 & 0.03 & 0.091 & 1.6 & 55.4 \\
\hline 2011 & & 0.089 & 2.8 & 54.2 \\
\hline 2012 & & 0.060 & 4.0 & 54.6 \\
\hline
\end{tabular}

Source: Authors' calculations based on data from the UN Commodity Trade Database, UNCTAD Handbook of Statistics 2008, State Bank of Pakistan annual reports, and various rounds of the Pakistan Economic Survey. 
In order to de-trend these series, each variable was regressed on time and the predicted values subtracted from the original series. Having carried out these transformations, the final model was estimated, the results of which are given in column 1 of Table 5 below. The model was reestimated with two-period lags for the GDP growth rate (column 2), the export growth rate (column 3), the real exchange rate (column 4), and the growth rate of world trade (column 5) in order to check the robustness of the results. ${ }^{2}$

\section{Table 5: Determinants of structural change in the export sector}

Dependent Variable: Structural Change Index

\begin{tabular}{|c|c|c|c|c|c|}
\hline & (1) & (2) & (3) & (4) & (5) \\
\hline \multirow[t]{2}{*}{ Liberalization } & 0.0193 & 0.0228 & 0.0137 & 0.0175 & 0.0192 \\
\hline & {$[0.01]$} & {$[0.01]$} & {$[0.02]$} & {$[0.02]$} & {$[0.01]$} \\
\hline \multirow[t]{2}{*}{ L1(Liberalization) } & 0.0207 & $-0.0284 *$ & 0.0235 & 0.0204 & 0.0226 \\
\hline & {$[0.01]$} & {$[0.01]$} & {$[0.01]$} & {$[0.01]$} & {$[0.01]$} \\
\hline \multirow[t]{2}{*}{ L2(Liberalization) } & $-0.0317 * * *$ & $-0.0360 * * *$ & $-0.0316 * * *$ & $-0.0311 * * *$ & $-0.0348 * * *$ \\
\hline & {$[0.01]$} & {$[0.01]$} & {$[0.01]$} & {$[0.01]$} & {$[0.01]$} \\
\hline \multirow[t]{2}{*}{ FD(Product Concentration Index) } & 0.0630 & 0.0619 & 0.0636 & 0.0623 & 0.0983 \\
\hline & {$[0.06]$} & {$[0.05]$} & {$[0.06]$} & {$[0.06]$} & {$[0.06]$} \\
\hline \multirow[t]{2}{*}{ L1(GDP Growth) } & 0.000443 & 0.000514 & 0.000667 & 0.000487 & 0.000572 \\
\hline & {$[0.00]$} & {$[0.00]$} & {$[0.00]$} & {$[0.00]$} & {$[0.00]$} \\
\hline L2(GDP Growth) & & $\begin{array}{l}0.00130 * * \\
{[0.00]}\end{array}$ & & & \\
\hline \multirow[t]{2}{*}{ L1(Exports Growth) } & -0.00561 & -0.0115 & -0.0117 & -0.00439 & -0.00852 \\
\hline & {$[0.01]$} & {$[0.01]$} & {$[0.01]$} & {$[0.01]$} & {$[0.01]$} \\
\hline L2(Exports Growth) & & & $\begin{array}{l}-0.000783 \\
{[0.00]}\end{array}$ & & \\
\hline \multirow[t]{2}{*}{ 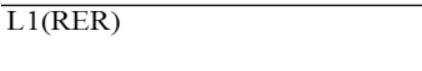 } & -0.000131 & -0.000140 & 0.0000105 & 0.0000360 & -0.0000397 \\
\hline & {$[0.00]$} & {$[0.00]$} & {$[0.00]$} & {$[0.00]$} & {$[0.00]$} \\
\hline \multirow[t]{2}{*}{ L2(RER) } & & & & -0.000187 & \\
\hline & & & & {$[0.00]$} & \\
\hline \multirow[t]{2}{*}{ L1(World Growth) } & -0.000131 & -0.00000167 & -0.0000678 & -0.000142 & -0.000155 \\
\hline & {$[0.00]$} & {$[0.00]$} & {$[0.00]$} & {$[0.00]$} & {$[0.00]$} \\
\hline L2(World Growth) & & & & & -0.000467 \\
\hline \multirow[t]{2}{*}{ Constant } & $0.0330^{* * *}$ & $0.0375 * * *$ & $0.0353 * * *$ & $0.0340 * * *$ & $0.0310^{* * *}$ \\
\hline & {$[0.01]$} & {$[0.01]$} & {$[0.01]$} & {$[0.01]$} & {$[0.01]$} \\
\hline $\mathrm{N}$ & 36 & 36 & 36 & 36 & 36 \\
\hline R-sq & 0.574 & 0.644 & 0.589 & 0.577 & 0.610 \\
\hline Adj. R-sq & 0.448 & 0.520 & 0.447 & 0.431 & 0.475 \\
\hline
\end{tabular}

Standard errors in brackets

$* \mathrm{p}<0.1, * * \mathrm{p}<0.05, * * * \mathrm{p}<0.01 "$

In all these estimations, the second-period lag of trade liberalization significantly explains variations in the SCI. As discussed in Section 2, trade liberalization is defined as the ratio of import duty revenues to total nonoil, nonfood imports, implying that an increase in this ratio would represent a

${ }^{2}$ The model was also estimated with lagged terms of the first-differenced product concentration index, but the results were not significantly different from zero. The model was also estimated with GDP growth, export growth, the real exchange rate, and world growth in levels but these variables did not emerge as significant determinants of the SCI. 
decrease in trade liberalization while a decrease in the ratio would represent an increase in trade liberalization. On the basis of this definition, the negative sign of the trade liberalization term in all the regression results can be interpreted as follows: a decrease in the ratio of import duty revenues to nonoil, nonfood imports (implying an increase in trade liberalization) is likely to increase medium-term structural change in the export sector.

This effect, however, takes place with a lag such that any measures aimed at decreasing the ratio of import duty revenues to nonoil, nonfood imports, i.e., increasing the degree of trade liberalization in the past, can be predicted to boost structural change in subsequent years. The country's GDP growth rate may also contribute to hastening the pace of mediumterm structural change in the export sector. Like trade liberalization, GDP growth is also expected to affect structural change with a two-period lag.

All other control variables, i.e., the first difference of the product concentration index, the export growth rate, the real exchange rate, and the growth rate of world trade, along with their one-period lags do not appear to have any significant impact on the SCI.

\section{Conclusion}

The objective of this study was to assess the degree of traditionality across all export industries in Pakistan, to analyze the degree of structural change that has occurred in the export sector since 1972, and to explore the determinants of medium-term structural change in the export sector.

Our results suggest that the current export base continues to be fairly traditional as is evident from the fact that the least traditional industries accounted for less than a tenth of total exports in 2012. Moreover, the results highlight two main factors that may be critical for the export sector to undertake structural change and become more dynamic in the future. The first of these pertains to a more liberal trade policy stance by the government; the second relates to the country's ability (as given by GDP growth) to successfully expand in the future.

However, the effectiveness of both measures-a more liberal trade policy regime and a sustained drive toward growth-will likely also depend on the availability of complementary fundamentals such as a supportive business environment, a trade-enabling regulatory framework, good governance with the rule of law, and political and macroeconomic stability. 


\section{References}

Ahmed, H., Hamid, N., \& Mahmud, M. (2013). Exports: Lessons from the past and the way forward. In R. Amjad \& S. J. Burki, Pakistan: Moving the economy forward (chap. 6). Lahore: Lahore School of Economics.

Ahmed, H., Mahmud, M., Hamid, N., \& Rahim, T. (2010). A strategy for reversing Pakistan's dismal export performance (Policy Paper No. 0110). Lahore: Centre for Research in Economics and Business.

Akbar, M., \& Naqvi, Z. F. (2001). External market conditions, competitiveness, diversification and Pakistan's export performance. Pakistan Development Review, 40(4, Pt. 2), 871-884.

Al-Marhubi, F. (2000). Export diversification and growth: An empirical investigation. Applied Economics Letters, 7(9), 559-562.

Felipe, J. (2007). A note on competitiveness and structural transformation in Pakistan (ERD Working Paper). Manila: Asian Development Bank.

Grossman, G., \& Helpman, E. (1991). Innovation and growth in the global economy. Cambridge, MA: MIT Press.

Gutiérrez-de-Piñeres, S. A., \& Ferrantino, M. (1997). Export diversification and structural dynamics in the growth process: The case of Chile. Journal of Development Economics, 52, 375-391.

Hausmann R., Hwang J., \& Rodrik D. (2005). What you export matters (Working Paper No. 11905). Cambridge, MA: National Bureau of Economic Research.

Krugman, P. (1979). A model of innovation, technology transfer and the world distribution of income. Journal of Political Economy, 87(2), 253-266.

Prebisch, R. (1950). The economic development of Latin America and its principal problems. New York, NY: United Nations.

Rosenstein-Rodan, P. (1943). Problems of industrialization of Eastern and South-eastern Europe. The Economic Journal, 53, 202-211. 
Singer, H. (1950). The distribution of gains between investing and borrowing countries. American Economic Review, 40(2), 473-485.

United Nations Conference on Trade and Development. (2008). UNCTAD Handbook of Statistics 2008. Geneva: Author.

United Nations Statistics Division. (2014). UN comtrade [Database]. Retrieved on 1 January 2014, from http://comtrade.un.org/

Vernon, R. (1966). International investment and international trade in the product cycle. Quarterly Journal of Economics, 80, 190-207.

World Bank. (2013). Finding the path to job-enhancing growth: A country economic memorandum (chap. 3) (Report No. 75521-PK). Washington, DC: Author.

World Bank. (2014). World development indicators [Database]. Available at http://data.worldbank.org/data-catalog/world-developmentindicators. 
Annex

Table A1: Export industries ranked by traditionality

\begin{tabular}{|c|c|c|c|c|c|}
\hline (1) & (2) & (3) & (4) & (5) & (6) \\
\hline $\begin{array}{l}\text { UN } \\
\text { code }\end{array}$ & Description & $\overline{4}$ & 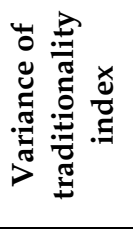 & 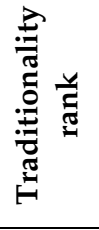 & 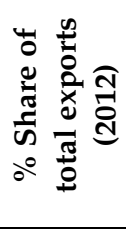 \\
\hline 01 & Meat and meat preparations & 0.095 & 0.048 & 1 & 0.86 \\
\hline 02 & Dairy products and birds' eggs & 0.115 & 0.056 & 2 & 0.32 \\
\hline 57 & Plastics in primary form & 0.124 & 0.067 & 3 & 1.55 \\
\hline 43 & Animal or vegetable fats and oils & 0.128 & 0.088 & 4 & 0.89 \\
\hline 28 & Metalliferous ores and metal scrap & 0.161 & 0.054 & 5 & 1.18 \\
\hline 82 & Furniture and parts thereof & 0.173 & 0.079 & 6 & 0.37 \\
\hline 51 & Organic chemicals & 0.204 & 0.065 & 7 & 0.74 \\
\hline 66 & $\begin{array}{l}\text { Nonmetallic mineral manufactures } \\
\text { n.e.s. }\end{array}$ & 0.218 & 0.051 & 8 & 2.55 \\
\hline 74 & $\begin{array}{l}\text { General industrial machinery and } \\
\text { equipment n.e.s. and machine parts } \\
\text { n.e.s. }\end{array}$ & 0.237 & 0.082 & 9 & 0.31 \\
\hline 54 & $\begin{array}{l}\text { Medicinal and pharmaceutical } \\
\text { products }\end{array}$ & 0.239 & 0.077 & 10 & 0.68 \\
\hline 67 & Iron and steel & 0.260 & 0.059 & 11 & 0.78 \\
\hline 84 & $\begin{array}{l}\text { Articles of apparel and clothing } \\
\text { accessories }\end{array}$ & 0.288 & 0.098 & 12 & 17.12 \\
\hline 69 & Manufactures of metals n.e.s. & 0.298 & 0.068 & 13 & 0.91 \\
\hline 33 & $\begin{array}{l}\text { Petroleum, petroleum products and } \\
\text { related materials }\end{array}$ & 0.301 & 0.067 & 14 & 1.34 \\
\hline 89 & Misc manufactured articles n.e.s. & 0.306 & 0.075 & 15 & 8.62 \\
\hline 05 & Vegetables and fruit & 0.318 & 0.071 & 16 & 2.24 \\
\hline 72 & $\begin{array}{l}\text { Machinery specialized for particular } \\
\text { industries }\end{array}$ & 0.339 & 0.083 & 17 & 0.31 \\
\hline 85 & Footwear & 0.363 & 0.083 & 18 & 0.42 \\
\hline 65 & $\begin{array}{l}\text { Textile yarn, fabrics, made-up articles } \\
\text { n.e.s., and related products }\end{array}$ & 0.363 & 0.092 & 19 & 35.37 \\
\hline 06 & Sugars, sugar preparations, and honey & 0.386 & 0.104 & 20 & 1.03 \\
\hline 27 & Crude fertilizers and crude minerals & 0.398 & 0.049 & 21 & 0.61 \\
\hline 87 & $\begin{array}{l}\text { Professional, scientific, and controlling } \\
\text { instruments }\end{array}$ & 0.403 & 0.090 & 22 & 1.28 \\
\hline 04 & Cereals and cereal preparations & 0.438 & 0.066 & 23 & 9.44 \\
\hline 03 & Fish and preparations thereof & 0.448 & 0.090 & 24 & 1.11 \\
\hline 61 & Leather and leather manufactures & 0.465 & 0.092 & 25 & 1.91 \\
\hline
\end{tabular}




\begin{tabular}{|c|c|c|c|c|c|}
\hline (1) & (2) & (3) & (4) & (5) & (6) \\
\hline $\begin{array}{l}\text { UN } \\
\text { code }\end{array}$ & Description & 焉 & 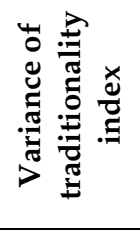 & 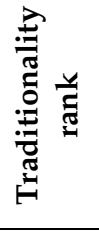 & 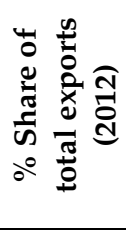 \\
\hline 07 & $\begin{array}{l}\text { Coffee, tea, cocoa, spices, and } \\
\text { manufactures thereof }\end{array}$ & 0.489 & 0.077 & 26 & 0.27 \\
\hline 29 & Crude animal and vegetable materials & 0.497 & 0.079 & 27 & 1.10 \\
\hline 93 & $\begin{array}{l}\text { Special transactions and commodities } \\
\text { not classified according to kind }\end{array}$ & 0.505 & 0.068 & 28 & 1.21 \\
\hline 26 & Textile fibers and their waste & 0.583 & 0.105 & 29 & 2.10 \\
\hline 08 & Feeding stuffs for animals & 0.678 & 0.050 & 30 & 0.30 \\
\hline
\end{tabular}

Note: In Tables 2 and 3, column 5 is based on the ranking of the top 30 2-digit export industries by their export share.

Source: Authors' calculations based on data from the UN Commodity Trade database. 